U.S. Department of the Interior

U.S. Geological Survey

\title{
Quality-Assurance Data, Comparison to Water-Quality Standards, and Site Considerations for Total Dissolved Gas and Water Temperature, Lower Columbia River, Oregon and Washington, 2001
}

By DWIGHT 0. TANNER and HEATHER M. BRAGG

Water-Resources Investigations Report 01-4273

Prepared in cooperation with the U.S. ARMY CORPS OF ENGINEERS

Portland, Oregon: 2001 


\section{U. S. DEPARTMENT OF THE INTERIOR \\ GALE A. NORTON, Secretary}

U.S. GEOLOGICAL SURVEY

CHARLES G. GROAT, Director

The use of trade, product, or firm names in this publication is for descriptive purposes only and does not imply endorsement by the U.S. Government.

For additional information:

\section{District Chief}

U.S. Geological Survey

10615 S.E. Cherry Blossom Dr.

Portland, OR 97216-3159

Internet URLs:

Oregon Water Resources: http://or.water.usgs.gov
Copies of this report may be purchased from:

\author{
U.S. Geological Survey \\ Branch of Information Services \\ Box 25286 \\ Denver, CO 80225-0286
}

Suggested citation: Tanner, D.0., and Bragg, H.M., 2001, Quality-assurance data, comparison to water-quality standards, and site considerations for total dissolved gas and water temperature, lower Columbia River, Oregon and Washington, 2001: U.S. Geological Survey Water-Resources Investigations Report 01-4273, 14 p. 


\section{CONTENTS}

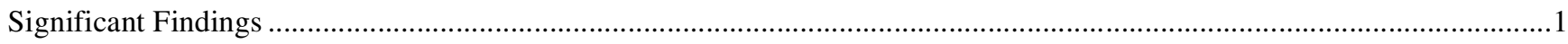

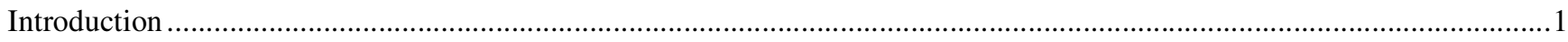

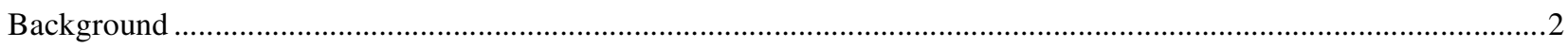

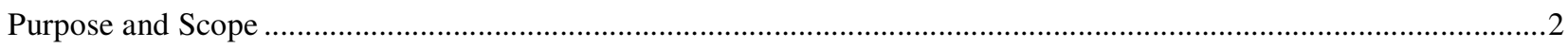

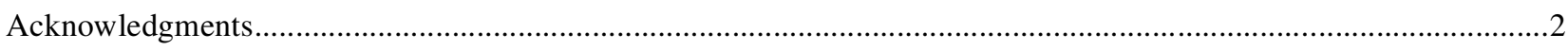

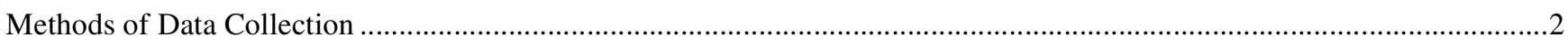

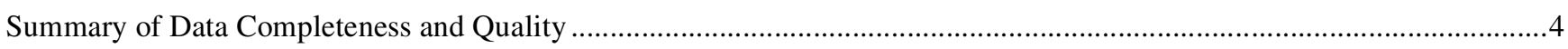

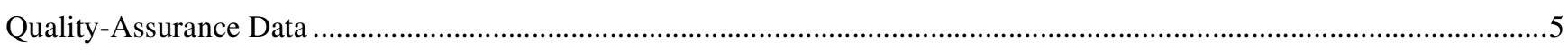

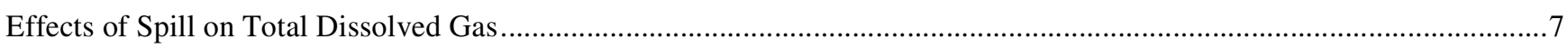

Comparison of Total Dissolved Gas and Temperature to Water-Quality Standards ...........................................................

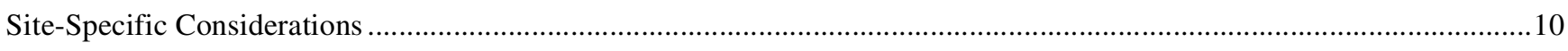

Variability of Total Dissolved Gas and Water Temperature at John Day Forebay ....................................................11

Variability of Total Dissolved Gas and Water Temperature at Camas....................................................................11

Lateral Distribution of Total Dissolved Gas at the Skamania-Warrendale Cross Section............................................12

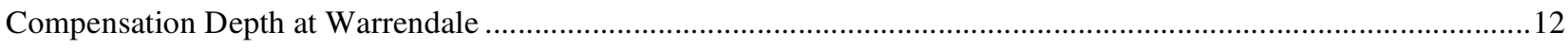

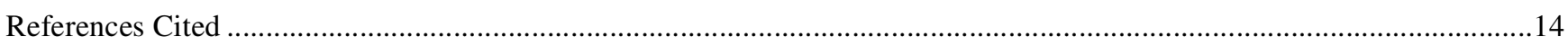

\section{FIGURES}

1. Map showing the location of total-dissolved-gas fixed stations, lower Columbia River, Oregon and Washington, water year 2001

2.-15. Graphs showing:

2. Accuracy of total-dissolved-gas sensors when compared to a certified pressure gauge

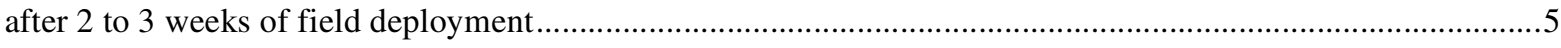

3. Difference between the secondary standard and the field barometers ................................................................ 6

4. Difference between the secondary standard and the field temperature instrument .............................................6

5. Difference between the secondary standard and the field total-dissolved-gas instrument ...................................6

6. Total dissolved gas above and below John Day Dam and spill over John Day Dam .........................................8

7. Total dissolved gas above and below The Dalles Dam and spill over The Dalles Dam ........................................8

8. Total dissolved gas above and below Bonneville Dam and spill over Bonneville Dam ....................................9

9. Total-dissolved-gas distributions and Oregon standards at the eight monitoring sites.......................................10

10. Water-temperature distributions at the eight monitoring sites from April 1 to September 15, 2001 .................10

11. Water-temperature distributions at the eight monitoring sites on August 29, 2001 .........................................10

12. Total dissolved gas at John Day forebay and water temperature at John Day forebay

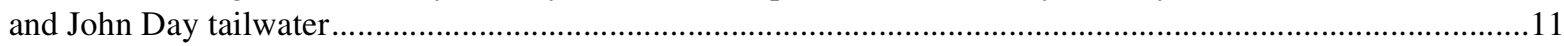

13. Diurnal variations of total dissolved gas and water temperature at Camas ......................................................12

14. Comparison of total dissolved gas at Warrendale and Skamania ...................................................................13

15. Compensation depth and actual probe depth at Warrendale ............................................................................ 14

\section{TABLES}

1. Total-dissolved-gas fixed stations, lower Columbia River, Oregon and Washington, water year 2001 .....................3

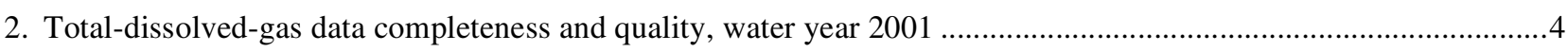


CONVERSION FACTORS

\begin{tabular}{rll}
\hline Multiply & By & To obtain \\
\hline inch (in.) & 25.4 & millimeter $(\mathrm{mm})$ \\
foot (ft) & 0.3048 & meter $(\mathrm{m})$ \\
mile $(\mathrm{mi})$ & 1.609 & kilometer $(\mathrm{km})$ \\
square mile $\left(\mathrm{mi}^{2}\right)$ & 2.590 & square kilometer $\left(\mathrm{km}^{2}\right)$ \\
cubic foot per second $(\mathrm{cfs})$ & 0.02832 & cubic meter per second \\
\hline
\end{tabular}

Temperature in degrees Celsius $\left({ }^{\circ} \mathrm{C}\right)$ may be converted to degrees Fahrenheit $\left({ }^{\circ} \mathrm{F}\right)$ as follows:

${ }^{\circ} \mathrm{F}=\left(1.8 \times{ }^{\circ} \mathrm{C}\right)+32$ 


\title{
Quality-Assurance Data, Comparison to Water-Quality Standards, and Site Considerations for Total Dissolved Gas and Water Temperature, Lower Columbia River, Oregon and Washington, 2001
}

\author{
By Dwight 0. Tanner and Heather M. Bragg
}

\section{SIGNIFICANT FINDINGS}

- For eight monitoring sites, in water year 2001, an average of $99.3 \%$ of the total-dissolved-gas data were received in real time and passed qualityassurance checks.

- After 2 to 3 weeks of deployment in the river, most comparisons of field total-dissolved-gas sensors with a secondary standard (another calibrated total-dissolved-gas sensor) were within $1 \%$.

- The only exceedances of Oregon water-quality standards for total dissolved gas occurred on May 23 and 24, 2001, at the Camas, Washington, station.

- At the forebay of the John Day Dam, temporary increases in water temperature and total dissolved gas occurred on hot afternoons during periods of low wind. These increases were not observed at the John Day tailwater station.

- At Camas, Washington, daily variations of total dissolved gas were probably due to the production of oxygen by aquatic plants and to water-temperature variations on warm, sunny days.

- During spill over Bonneville Dam in water year 2001, the site on the Oregon side of the Columbia River, Warrendale, measured larger total-dissolved-gas levels than the site directly across on the Washington side at Skamania. Apparently, streamflow through generating facilities on the north side of the dam forced supersaturated water from the spill bays over to the Oregon side of the river.
- At times in July and August 2001, the totaldissolved-gas probe at Warrendale could not be positioned below the minimum compensation depth because the river was too shallow at that location. Consequently, degassing at probe depth may have occurred, and total dissolved gas may have been larger in locations with greater depths.

\section{INTRODUCTION}

The U.S. Army Corps of Engineers (USACE) operates dams in the Columbia River Basin, which encompasses 259,000 square miles of the Pacific Northwest. These dams are multipurpose facilities that fill regional needs for flood control, navigation, irrigation, recreation, hydropower production, fish and wildlife habitat, water-quality maintenance, and municipal and industrial water supply. When water is released over the spillways of these dams, air is entrained in the water, increasing the concentration of total dissolved gas (TDG) downstream from the spillways. Consequently, TDG may exceed Oregon and Washington water-quality standards for the protection of freshwater aquatic life. Concentrations above $110 \%$ saturation have been shown to cause gas-bubble trauma in fish and adversely affect other aquatic organisms (U.S. Environmental Protection Agency, 1986). The USACE minimizes spill and regulates streamflow in the region to minimize the production of excess TDG downstream from its dams. The USACE also oversees the collection of real-time TDG and water-temperature data (data available within about 4 hours of current time) upstream and downstream from the dams in a network of fixed-station monitors. 


\section{Background}

Real-time TDG and water-temperature data are vital to the USACE for dam operation and for monitoring compliance with environmental regulations. The data are used by water managers to maintain waterquality conditions that facilitate fish passage and survival in the lower Columbia River. The U.S. Geological Survey (USGS), in cooperation with the Portland District of USACE, has collected TDG and related data in the lower Columbia River every year since 1996. Current TDG and water temperature data can be found on the USGS website at http://oregon. usgs.gov/ projs dir/pn307.tdg/. Reports that were published in 1996 and 2001 contained descriptions of the methods of data collection and quality-assurance data for water years (WY) 1996 and 2000, respectively (Tanner and others, 1996; Tanner and Johnston, 2001).

To provide a suitable data set for managing and modeling TDG in the lower Columbia River, real-time hourly data for WY 2001 were reviewed in relation to measurements made during instrument calibration. Some TDG data were deleted because they were not of suitable quality. The reviewed hourly data are stored in a USGS data base (Automated Data Processing System -ADAPS), and in the USACE data base (Columbia River Operation Hydromet Management SystemCROHMS), which also provides discharge and spill data at http://www.nwd-wc.usace.army.mil/TMT/tdg _data.

\section{Purpose and Scope}

The purpose of TDG monitoring in the lower Columbia River is to provide the USACE with (1) realtime data for managing streamflows and TDG levels upstream and downstream from its project dams and (2) reviewed TDG data to evaluate conditions in relation to water-quality standards and to develop a TDG data base for modeling the effect of various management scenarios of streamflow and spill on TDG levels.

This report describes the TDG data and related quality-assurance data for the monitoring program on the lower Columbia River, from the forebay of the John Day Dam (river mile [RM] 215.6) to Camas, Washington (RM 121.7). Data for WY 2001 (October 1, 2000 through September 30, 2001) included TDG pressure, barometric pressure, water temperature, and probe depth at eight fixed stations on the lower Columbia River (fig. 1, table 1).

\section{Acknowledgments}

We wish to acknowledge the aid and funding support of the U.S. Army Corps of Engineers. Our special thanks to James L. Britton (USACE) for technical and logistical support of the project. The authors also acknowledge Matt Johnston and Amy Brooks (USGS) for assistance in data collection and for preparing summaries and analyses of data. Rebecca Treat, a USGS volunteer, also assisted with data collection in the field.

\section{METHODS OF DATA COLLECTION}

Methods of data collection for TDG, barometric pressure, and water temperature are described in detail in Tanner and Johnston (2001). A summary of these methods follows. Instrumentation at each fixed station consisted of a Hydrolab water-quality probe; a Common Sensing, Inc., electronic barometer; a power supply; and a Sutron Model 8200 data-collection platform (DCP). The barometer, probe, and DCP were powered by a 12-volt battery that was charged by a solar panel and/or a 120-volt alternating-current line. Every 4 hours, the DCP transmitted the most recent logged data to the Geostationary Operational Environmental Satellite (GOES) system (Jones and others, 1991). The data were automatically decoded and transferred to the USACE CROHMS data base, and to the USGS ADAPS data base. At the John Day tailwater station, two TDG sensors were installed on the same Hydrolab. This was done to ensure that data were reliably collected at this important site and to provide an assessment of the variability of the TDG measurement at a single point in the river cross section.

The fixed-station monitors were calibrated every 2 weeks from March 10 to September 15, 2001, and every 3 weeks for the remainder of the year, at which time Warrendale and Bonneville forebay were the only sites in operation. The field calibration procedure was as follows: A recently calibrated Hydrolab (which was used as a secondary standard) was deployed alongside of the field Hydrolab to obtain check measurements of TDG and water temperature prior to removing the field Hydrolab for calibration. Then the field Hydrolab was replaced with one that had been recently calibrated at the Oregon District laboratory. Again, the secondary standard instrument was used to check TDG and temperature in the river. The electronic barometer at the fixed station was calibrated using a portable barometer that had been recently calibrated. 


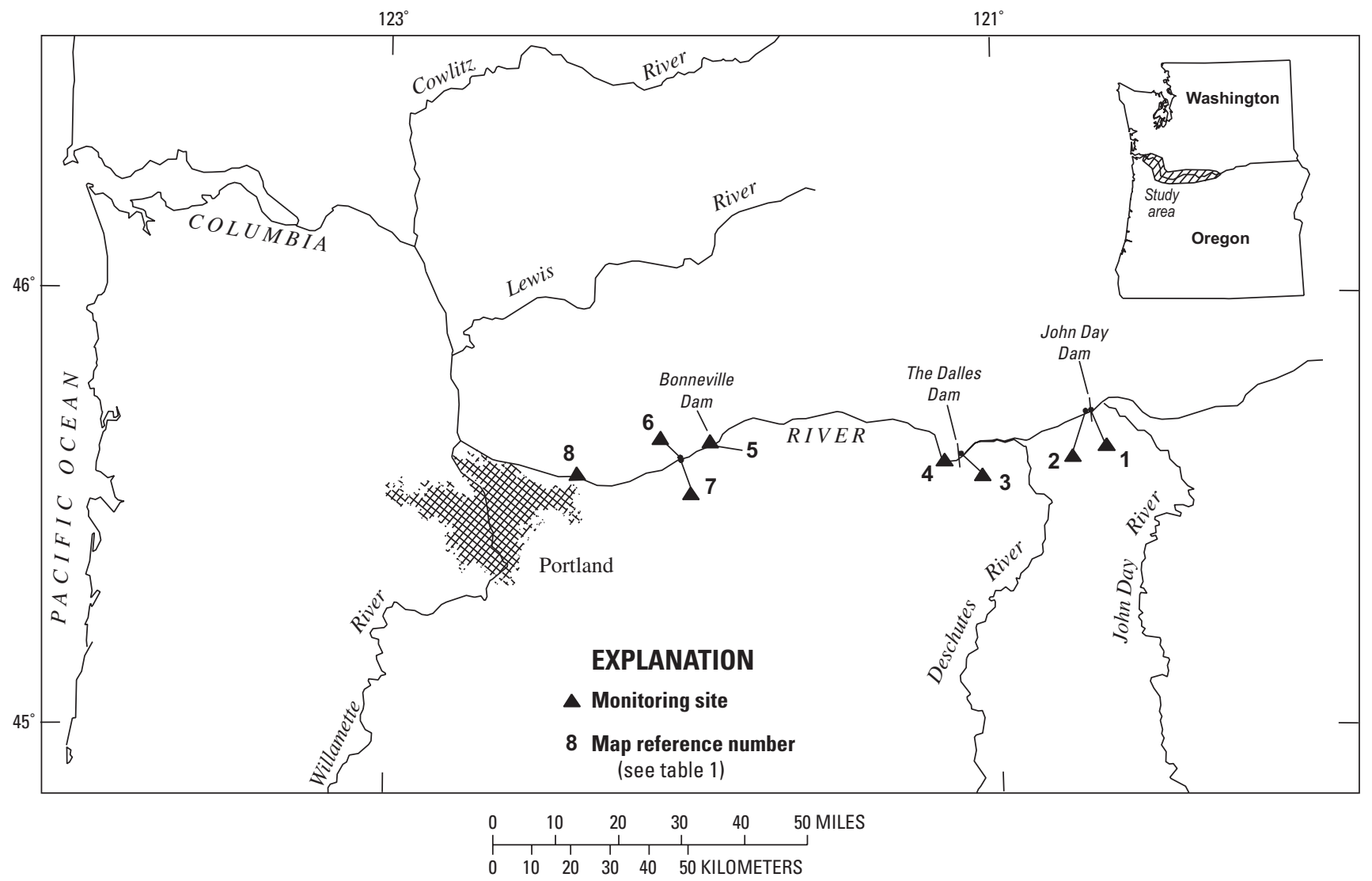

Figure 1. Total-dissolved-gas fixed stations, lower Columbia River, Oregon and Washington, water year 2001.

Table 1. Total-dissolved-gas fixed stations, lower Columbia River, Oregon and Washington, water year 2001

[Map reference number refers to figure 1; USACE, U.S. Army Corps of Engineers; Columbia River mile locations were determined from U.S. Geological Survey (USGS) 7.5-minute topographic maps; stations are referenced by their abbreviated name or USACE site identifier in this report; ', degree; ', minute; ", second]

\begin{tabular}{|c|c|c|c|c|c|c|c|}
\hline $\begin{array}{c}\text { Map } \\
\text { reference } \\
\text { number }\end{array}$ & $\begin{array}{c}\text { USACE } \\
\text { site } \\
\text { identifier }\end{array}$ & $\begin{array}{c}\text { Columbia } \\
\text { River } \\
\text { mile }\end{array}$ & $\begin{array}{c}\text { USGS } \\
\text { station number }\end{array}$ & $\begin{array}{l}\text { USGS station name } \\
\text { (abbreviated station name) }\end{array}$ & Latitude & Longitude & $\begin{array}{l}\text { Period } \\
\text { of } \\
\text { record }\end{array}$ \\
\hline 1 & JDA & 215.6 & 454257120413000 & $\begin{array}{l}\text { Columbia River at John Day Dam forebay, } \\
\text { Washington (John Day forebay) }\end{array}$ & $45^{\circ} 42^{\prime} 57^{\prime \prime}$ & $120^{\circ} 41^{\prime} 30^{\prime \prime}$ & $\begin{array}{l}03 / 27 / 01- \\
09 / 20 / 01\end{array}$ \\
\hline 2 & JHAW & 214.7 & 454249120423500 & $\begin{array}{l}\text { Columbia River, right bank, near Cliffs, } \\
\text { Washington (John Day tailwater) }\end{array}$ & $45^{\circ} 42^{\prime} 49^{\prime \prime}$ & $120^{\circ} 42^{\prime} 35^{\prime \prime}$ & $\begin{array}{l}03 / 27 / 01- \\
09 / 20 / 01\end{array}$ \\
\hline 3 & TDA & 192.6 & 453712121071200 & $\begin{array}{l}\text { Columbia River at The Dalles Dam forebay, } \\
\text { Washington (The Dalles forebay) }\end{array}$ & $45^{\circ} 37^{\prime} 12^{\prime \prime}$ & $121^{\circ} 07^{\prime} 12^{\prime \prime}$ & $\begin{array}{l}03 / 28 / 01- \\
09 / 21 / 01\end{array}$ \\
\hline 4 & TDDO & 188.9 & 14105700 & $\begin{array}{l}\text { Columbia River at The Dalles, } \\
\text { Oregon (The Dalles tailwater) }\end{array}$ & $45^{\circ} 36^{\prime} 27^{\prime \prime}$ & $121^{\circ} 10^{\prime} 20^{\prime \prime}$ & $\begin{array}{l}03 / 28 / 01- \\
09 / 21 / 01\end{array}$ \\
\hline 5 & BON & 146.1 & 453845121562000 & $\begin{array}{l}\text { Columbia River at Bonneville Dam forebay, } \\
\text { Washington (Bonneville forebay) }\end{array}$ & $45^{\circ} 38^{\prime} 45^{\prime \prime}$ & $121^{\circ} 56^{\prime} 20^{\prime \prime}$ & Year-round \\
\hline 6 & SKAW & 140.5 & 453651122022200 & $\begin{array}{l}\text { Columbia River, right bank, near Skamania, } \\
\text { Washington (Skamania) }\end{array}$ & $45^{\circ} 36^{\prime} 51^{\prime \prime}$ & $122^{\circ} 02^{\prime} 22^{\prime \prime}$ & $\begin{array}{l}02 / 27 / 01- \\
09 / 20 / 01\end{array}$ \\
\hline 7 & WRNO & 140.4 & 453630122021400 & $\begin{array}{l}\text { Columbia River, left bank, near Dodson, } \\
\text { Oregon (Warrendale) }\end{array}$ & $45^{\circ} 36^{\prime} 30^{\prime \prime}$ & $122^{\circ} 02^{\prime} 14^{\prime \prime}$ & Year-round \\
\hline 8 & CWMW & 121.7 & 453439122223900 & $\begin{array}{l}\text { Columbia River, right bank, at Washougal, } \\
\text { Washington (Camas) }\end{array}$ & $45^{\circ} 34^{\prime} 39^{\prime \prime}$ & $122^{\circ} 22^{\prime} 39^{\prime \prime}$ & $\begin{array}{l}02 / 27 / 01- \\
09 / 19 / 01\end{array}$ \\
\hline
\end{tabular}


The Hydrolab that had been deployed for 2 to 3 weeks was then calibrated in the Oregon District laboratory. The integrity of the TDG membrane was checked, and the TDG sensor was calibrated at 100, 200, and $300 \mathrm{~mm} \mathrm{Hg}$ (millimeters of mercury) above atmospheric pressure to cover the expected range of TDG pressure in the river.

During each field calibration, the minimum compensation depth was calculated to determine whether the Hydrolab was positioned at an appropriate depth to measure TDG. This depth, which was calculated according to Colt (1984, p. 104), is the depth above which degassing will occur due to decreased hydrostatic pressure. To measure TDG accurately, the Hydrolabs were positioned during each calibration visit at a depth below the minimum calculated compensation depth, whenever possible.

\section{SUMMARY OF DATA COMPLETENESS AND QUALITY}

Year-end summaries of water year 2001 TDG data completeness and quality are shown in table 2. Data in this table are based on the total amount of hourly TDG data and barometric-pressure data that could have been collected during the scheduled monitoring season. At all part-year stations, more data were collected than was scheduled because the monitors were set up early to ensure correct operation. Any hour without TDG-pressure data or barometric-pressure data was counted as an hour of missing data for TDG in percent saturation, which is calculated as TDG pressure, in millimeters of mercury, divided by the barometric pressure, in millimeters of mercury, multiplied by 100 . The percentage of real-time data received shown in table 2 represents the data that were received via satellite telemetry at the USGS downlink. The USACE downlink operated independently, but the amount and quality of the data were similar.

At each station, at least $98.8 \%$ of the data was received real-time by the USGS downlink, with an overall average of $99.7 \%$ (table 2). Problems with the amount of real-time data received were usually due to malfunction or mistakes in programming of the data-collection platform. At Bonneville forebay, realtime data were lost on several occasions in October because a large maintenance crane was blocking the DCP antenna.
The fourth column in table 2 shows the percentage of data that was received real-time and passed quality-assurance checks. TDG data were considered to meet quality-assurance standards if they were within $1 \%$ TDG of the expected value, based on calibration data and ambient river conditions at adjacent sites. The lowest percentage for a station was $97.8 \%$ at The Dalles forebay (site 3). Most of this data loss occurred in June, when the logged TDG values were constant for hours at a time, indicating that the data were not being updated. Several field visits were made before the problem was resolved by sequentially replacing equipment, but the missing data could not be recovered. Most other problems with meeting quality-assurance standards were related to the TDG membrane leaking or tearing. At Warrendale on July 14, 7 hours of TDG data were deleted because the TDG membrane became buried in the mud as the river stage fell. The overall average of real-time data passing quality-assurance standards was $99.3 \%$.

The collection of barometric-pressure and water-temperature data had fewer complications than did TDG data collection. Except for instances where all data parameters were missing due to problems with the DCP, there were only a few hours of missing or incorrect barometric-pressure or watertemperature data.

Table 2. Total-dissolved-gas data completeness and quality, water year 2001

[TDG, total dissolved gas]

\begin{tabular}{lccc}
\hline $\begin{array}{c}\text { Abbreviated } \\
\text { station name }\end{array}$ & $\begin{array}{c}\text { Planned } \\
\text { monitoring, } \\
\text { in hours }\end{array}$ & $\begin{array}{c}\text { Percentage of } \\
\text { real-time TDG } \\
\text { data received }\end{array}$ & $\begin{array}{c}\text { Percentage of } \\
\text { real-time TDG } \\
\text { data passing } \\
\text { quality assurance }\end{array}$ \\
\hline John Day forebay & 4,032 & 99.3 & 98.3 \\
John Day tailwater & 4,032 & 100.0 & 100.0 \\
The Dalles forebay & 4,032 & 99.8 & 97.8 \\
The Dalles tailwater & 4,032 & 100.0 & 100.0 \\
Bonneville forebay & 8,760 & 98.8 & 98.8 \\
Skamania & 4,560 & 99.8 & 99.8 \\
Warrendale & 8,760 & 100.0 & 99.9 \\
Camas & 4,560 & 100.0 & 100.0 \\
\hline \hline
\end{tabular}




\section{QUALITY-ASSURANCE DATA}

Data collection for TDG, barometric pressure, and water temperature included several qualityassurance procedures, such as the calibration of instruments in the field and in the laboratory, daily checks of the data, and data review and archive. These methods are explained in detail in Tanner and Johnston (2001), and the results of the quality-assurance data for WY 2001 are presented in this section.

After field deployment for 2 or 3 weeks, the TDG sensors were calibrated in the laboratory. First, the unit was tested, with the membrane in place, for response to increased pressure and to super-saturation conditions. The membrane was then removed from the sensor and allowed to dry for at least 24 hours. Before replacing the membrane, the TDG sensor was examined independently. The calibration test procedure involved reading the TDG sensor at the barometric pressure (100\% saturation) and, using a certified digital pressure gauge (primary standard), at added pressures of 100, 200, and $300 \mathrm{~mm} \mathrm{Hg}$ (approximately 113\%, 126\% and 139\% saturation, respectively). The accuracy of the TDG sensors was calculated by computing the difference between the expected reading and the Hydrolab TDG sensor reading (expected minus actual) for each of the four test conditions. As shown in figure 2, most of the differences were within $0.4 \%$ saturation. There are two groups of outlying data. The data points above $1 \%$ saturation for the $100 \%, 113 \%$, and $126 \%$ test conditions were the result of a faulty TDG sensor that had been deployed at The Dalles forebay for 2 weeks. During the subsequent laboratory testing, the sensor would not accept calibration. The group of data points below $-1 \%$ saturation for the $113 \%, 126 \%$, and $139 \%$ test conditions was also the result of a malfunctioning TDG sensor. This sensor was calibrated at $100 \%$ and $126 \%$ saturation in the laboratory but continued to read inaccurately when retested. This malfunctioning sensor affected 6 days of data at Warrendale. Both units were removed from field use and sent to the manufacturer for repair.

The differences in barometric pressure, water temperature, and TDG between a secondary standard instrument and the fixed-station monitors after 2 to 3 weeks of field deployment were measured and recorded as part of the field inspection and calibration procedure.

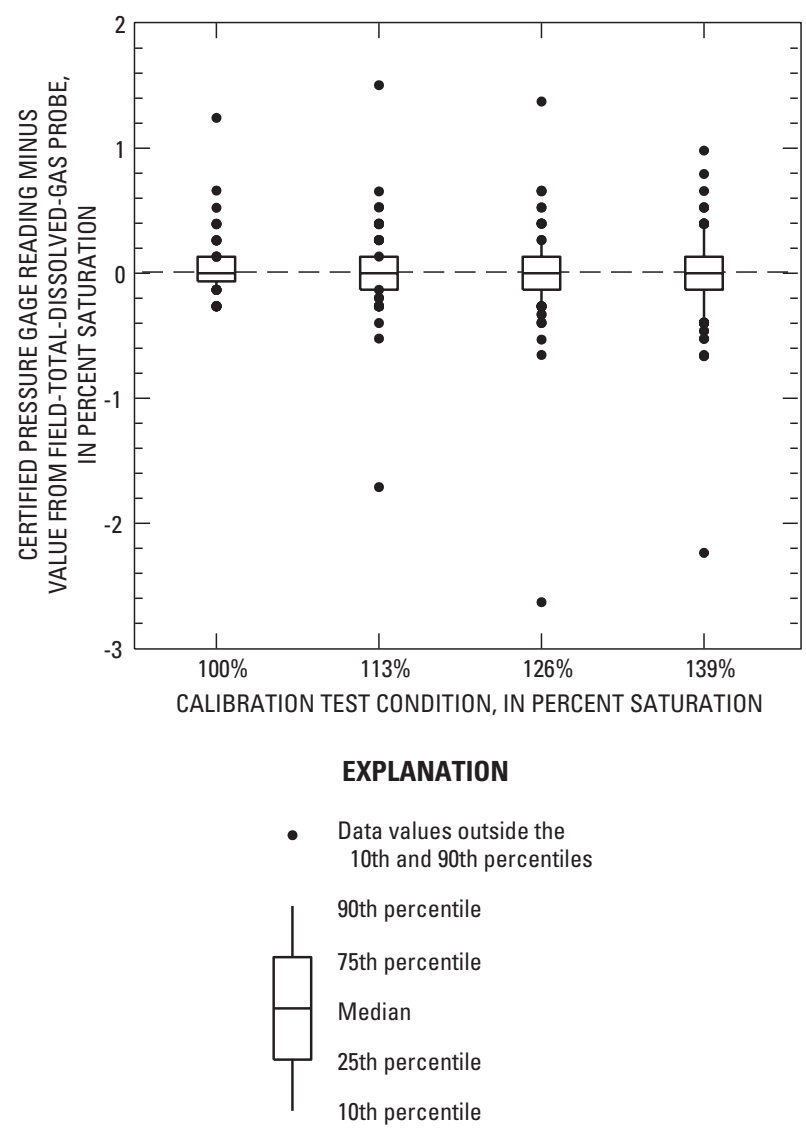

Figure 2. Accuracy of total-dissolved-gas sensors when compared to a certified pressure gauge after 2 to 3 weeks of field deployment. (There were 131 tests at each pressure.)

These differences, defined as the secondary standard value minus the field instrument value, were used to compare and quantify the precision between two independent instruments. For water temperature and TDG, the measurements were made in-situ with the secondary standard (a recently calibrated Hydrolab) positioned alongside of the field Hydrolab in the river. Figures 3, 4, and 5 illustrate the distribution of qualityassurance data for each of the three parameters from all eight field sites.

The comparisons of the aneroid barometer used as a secondary standard and the electronic field barometer are shown in figure 3. Most of the field values are within $2 \mathrm{~mm} \mathrm{Hg}$ of the standard values. Several of the outlying points reflect calibrations of the field barometers (adjustment of the DCP offset values) shortly after the site installations in the spring. 


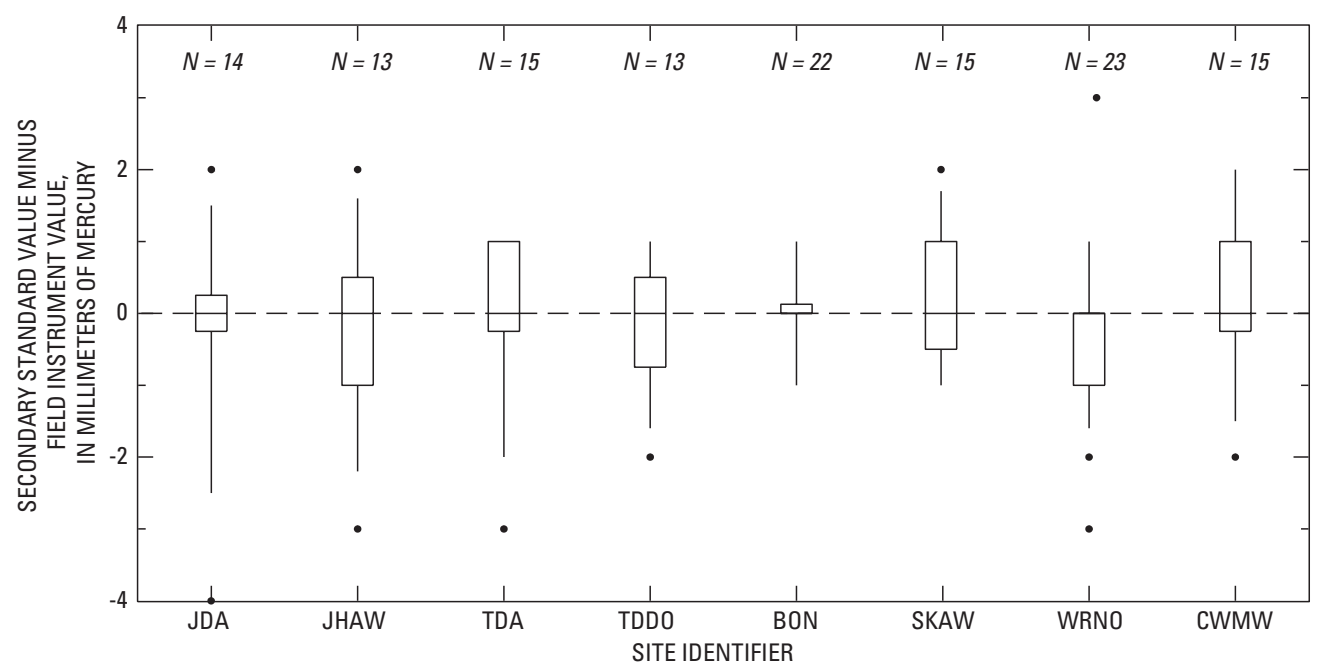

EXPLANATION

Data values outside the 10th and 90th percentiles 90th percentile

75th percentile

Median

25th percentile

10th percentile

$N=22 \quad$ Number of samples

Figure 3. Difference between the secondary standard and the field barometers. (Refer to table 1 for site identifier.)

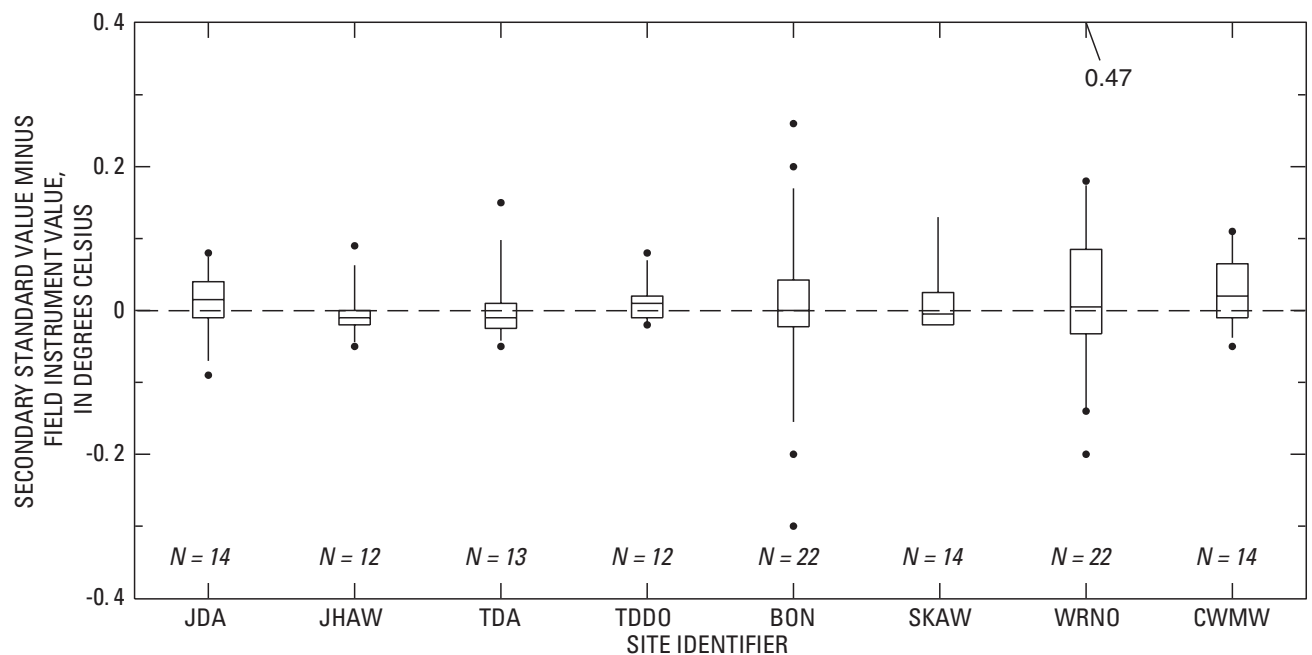

EXPLANATION

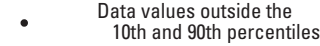

90th percentile

75th percentile

Median

25th percentile

10th percentile

$N=22 \quad$ Number of samples

Figure 4. Difference between the secondary standard and the field temperature instrument. (Refer to table 1 for site identifier.)

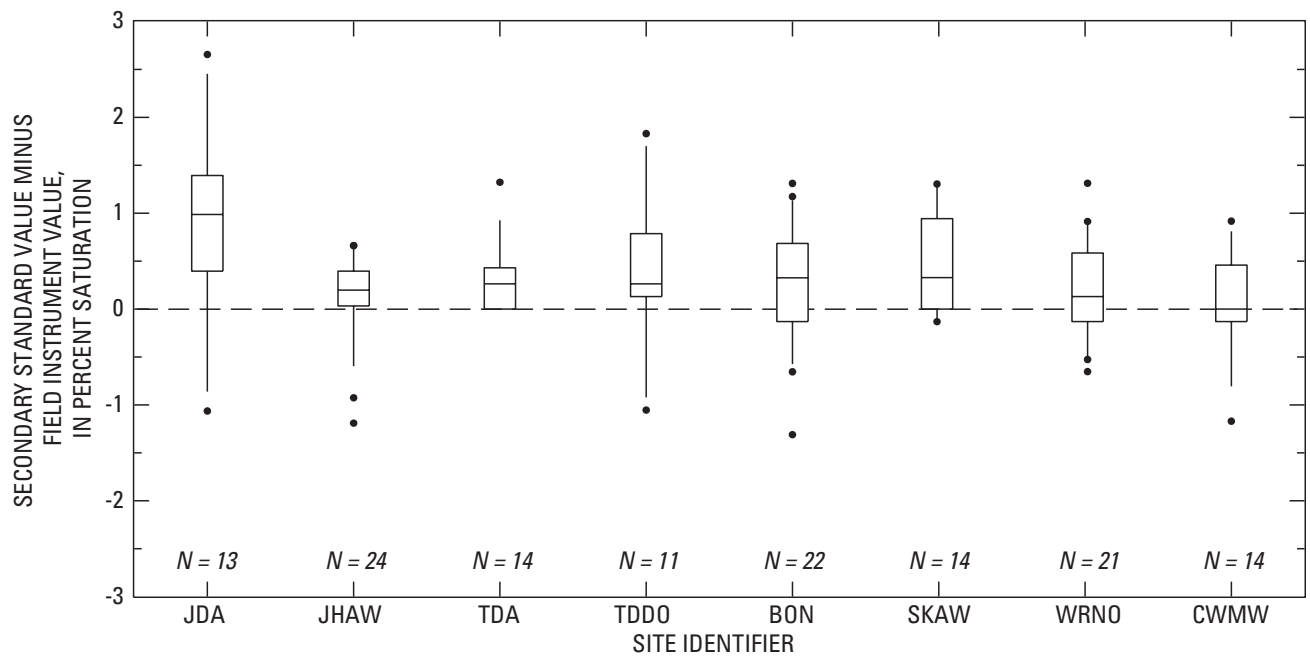

EXPLANATION

Data values outside the 10th and 90th percentiles

90th percentile

75th percentile

Median

25th percentile

10th percentile

$N=22 \quad$ Number of samples

Figure 5. Difference between the secondary standard and the field total-dissolved-gas instrument. (Refer to table 1 for site identifier.) 
The temperature-sensor secondary standard and the field temperature sensor results are presented in figure 4. Most of the differences are within $0.1^{\circ} \mathrm{C}$ (degrees Celsius). The slightly wider distribution of values for the Bonneville forebay and Warrendale sites may be the result of a larger data set. These two sites were in operation year-round, nearly twice as long as the other six sites. The one significant outlier $\left(+0.47^{\circ} \mathrm{C}\right)$ occurred at Warrendale. Shortly after its field deployment at this site, the temperature sensor demonstrated obvious malfunction and was removed from field use for the remainder of the year.

The differences between the TDG sensor used as a secondary standard and the field TDG sensors were calculated following equilibration of the secondary standard unit to the site conditions with both Hydrolabs side by side in the river. This equilibration was considered complete after a minimum of 20 minutes when the TDG values for each sensor remained constant for 4 to 5 minutes. As shown in figure 5, most of the data demonstrates less than $1 \%$ saturation difference between the two sensors; however, the site at John Day forebay often exceeded this value. Three different TDG probes were sequentially deployed for field operation at the site. Each probe gave similar results, suggesting instrument malfunction was not the cause of the larger TDG differences. Although the secondary standard and the field TDG sensors were positioned at approximately the same depth during these field checks, the field sensor was always positioned in the pipe housing and the secondary standard was positioned in the open water. During the low flows in WY 2001, partially stagnant water in the pipe housing may have caused these differences.

Duplicate TDG data were collected at John Day tailwater. Data from the two sensors on the same instrument showed smaller differences in WY 2001 than in WY 2000 (Tanner and Johnston, 2001) when two Hydrolabs were positioned at different depths in the pipe housing (one above the other). For WY 2001, there were 4,140 hourly values from March 27 to September 20, and $95 \%$ of the differences between the primary and the duplicate sensor were between -0.7 and $+0.1 \%$ saturation. There was little bias, with the median of the differences being $-0.1 \%$ saturation.

\section{EFFECTS OF SPILL ON TOTAL DISSOLVED GAS}

Spill over each dam increased the level of TDG, causing the monitoring site below the dam to have larger TDG levels than the site above the dam. Spill over John Day Dam occurred from May 25 to June 16 (fig. 6). The spill (between about 20,000 and 65,000 cfs [cubic feet per second]) was released during the evening hours. Figure 6 shows that TDG below John Day Dam increased in close response to spill over the dam, with a level of 113-115\% saturation being common. TDG levels above John Day Dam generally formed the baseline to which the tailwater site returned to when there was no spill. Exceptions to this return to baseline occurred on May 26, May 31, and June 1st. It is likely that during these periods, heating of a stagnant (nonmoving) pool of water near the fixed station caused a transient increase in TDG, as has been observed in the past.

Continuous spill over The Dalles Dam from May 16 to June 15 and July 24 to August 31 caused increased TDG at the site below The Dalles Dam (fig. 7). Spill of about 15,000 to about $65,000 \mathrm{cfs}$ caused TDG levels below the dam to increase to about 108-113\% saturation. During periods of no spill, the TDG level above and below The Dalles Dam were essentially identical (fig. 7).

At Bonneville Dam, there were three periods of spill in WY 2001 (fig. 8). From March 10 to March 13, there were periods of nighttime spill of about 47,000 cfs to flush released hatchery fish to the ocean. The TDG at Warrendale during these spills increased to about $113-114 \%$. Nearly continuous spill of about 50,000 cfs from May 16 to June 15 resulted in TDG levels of about $113-116 \%$ at Warrendale. Finally, periods of nighttime and continuous spill of about 50,000 cfs from July 24 to August 31 caused TDG levels at Warrendale to rise to about 110-113\%. As expected, during times of no spill, the TDG level at Bonneville forebay was very similar to the level below Bonneville Dam at Warrendale (fig. 8). 

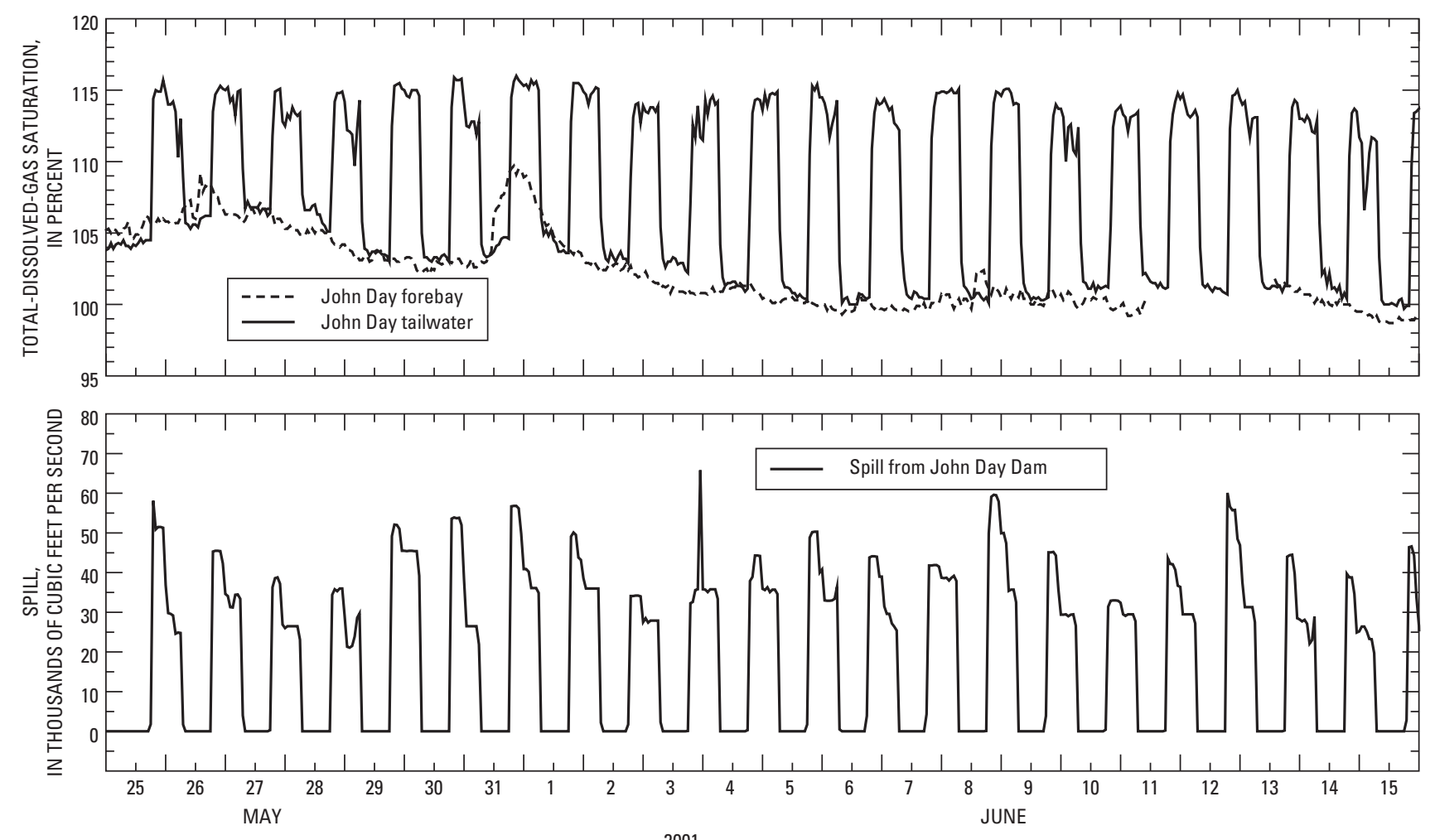

Figure 6. Total dissolved gas above and below John Day Dam and spill over John Day Dam.
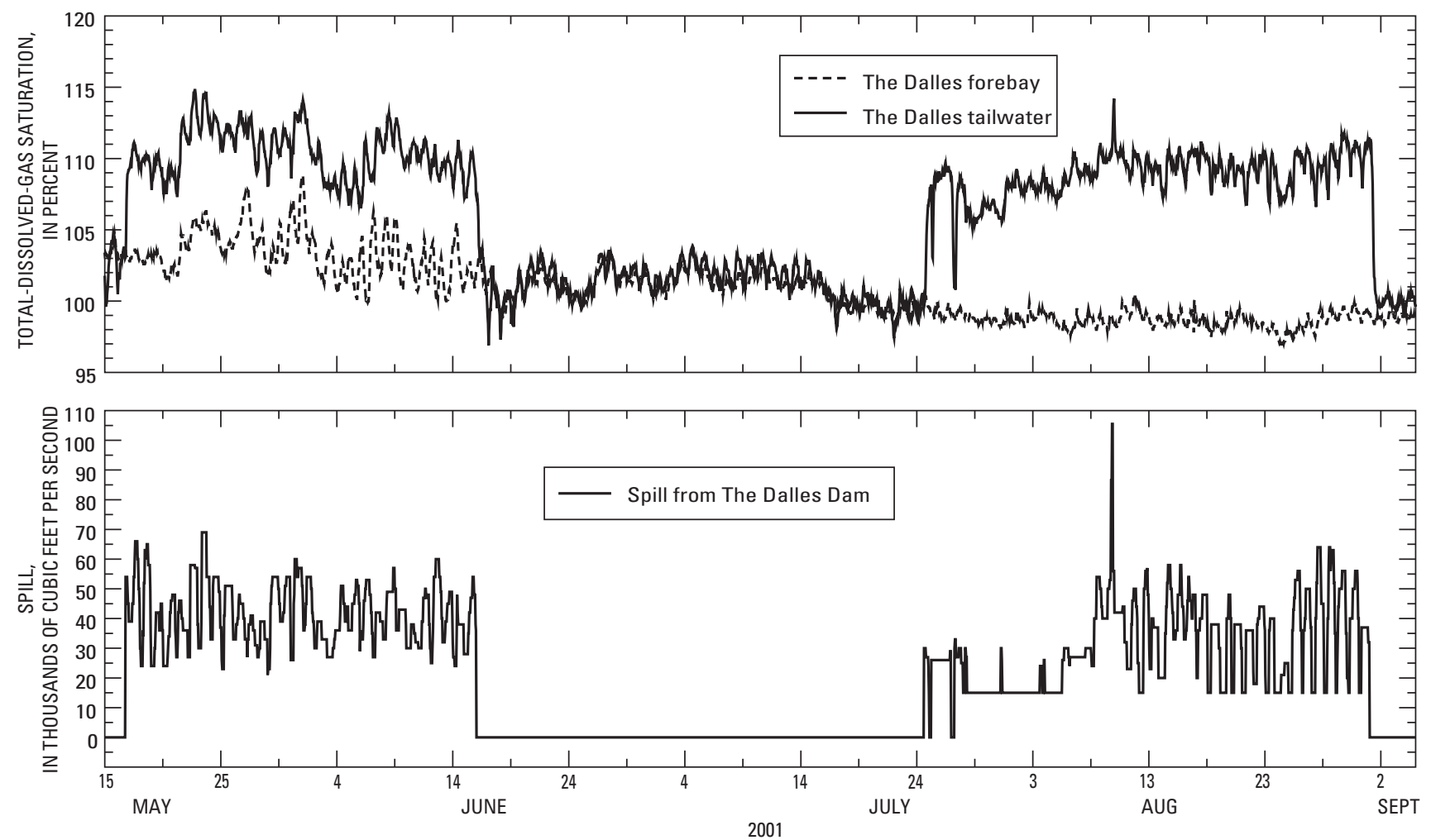

Figure 7. Total dissolved gas above and below The Dalles Dam and spill over The Dalles Dam. 

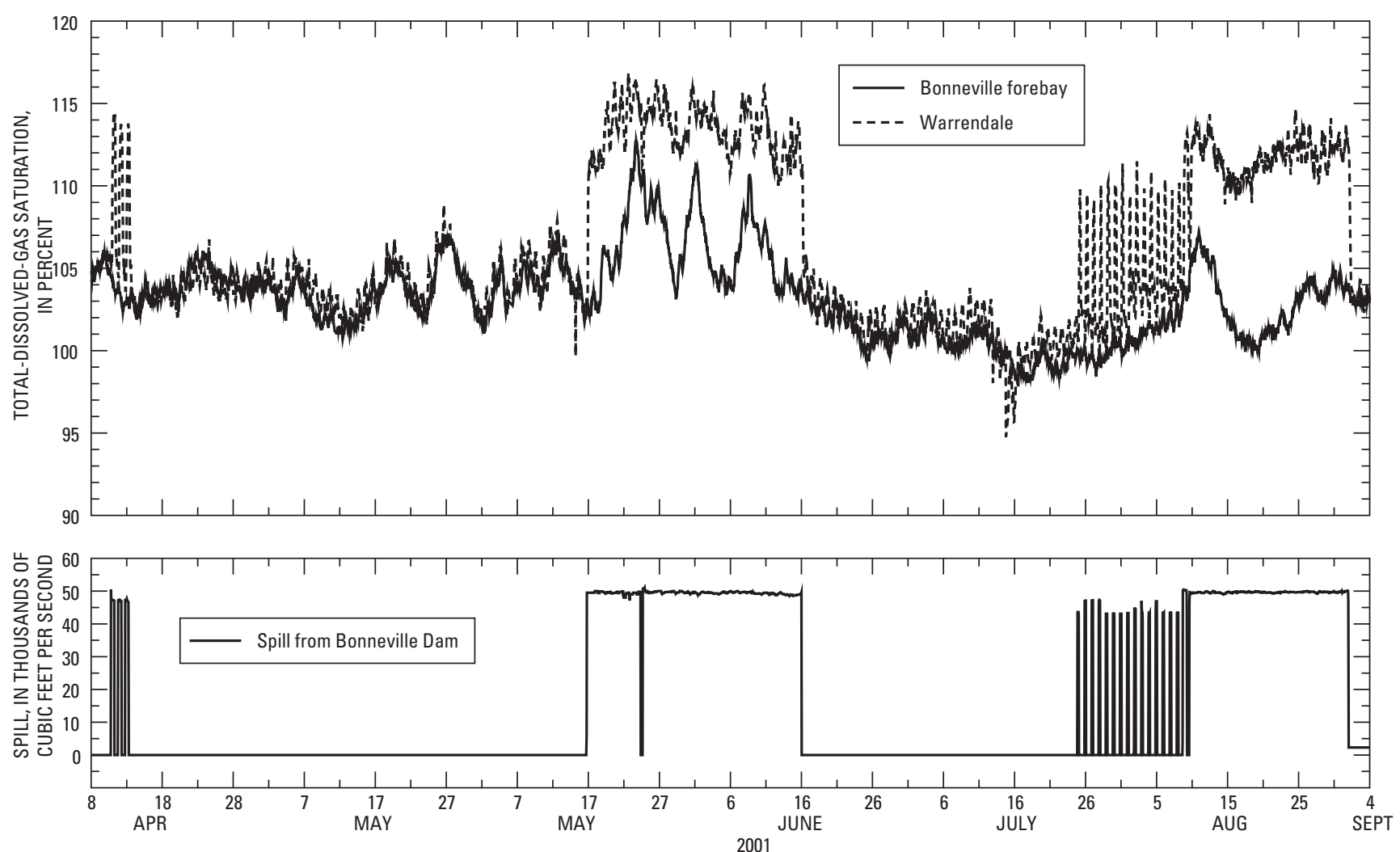

Figure 8. Total dissolved gas above and below Bonneville Dam and spill over Bonneville Dam.

\section{COMPARISON OF TOTAL DISSOLVED GAS AND TEMPERATURE TO WATER-QUALITY STANDARDS}

Oregon water-quality standards for TDG and water temperature for the lower Columbia River are similar to Washington standards. In this report, Oregon standards specifically are addressed. The USACE may obtain a variance from the Oregon TDG water-quality standard of $110 \%$ saturation relative to atmospheric pressure for a specified period of time to facilitate fish passage. From April 10 to August 31, 2001, the variance was $115 \%$ for forebay sites (John Day forebay, The Dalles forebay, Bonneville forebay, and Camas) and the variance was $120 \%$ for tailwater sites directly downstream from dams (John Day tailwater, The Dalles tailwater, Warrendale, and Skamania).

Although the Camas site is not located in the forebay of a dam, it is located more than 24 miles downstream of Bonneville Dam and is regulated as a forebay site. The variance was exceeded if the average of the highest 12 hourly values in 1 day (1:00 a.m. to midnight) was larger than the numerical standard (Stephanie Hallock, Oregon Department of Environmental Quality, written commun., March 23, 2001). In addition, TDG should not exceed $125 \%$ saturation, based on the highest 2 hours during the 12 highest hourly measurements per day.

The distribution of all the hourly TDG measurements in WY 2001 is shown on figure 9, in relation to the Oregon numerical standards. The hourly values for all of the sites did not exceed $118 \%$ saturation. Analysis of the hourly values showed that the Camas site was the only site for which the 12-hour average was in exceedance of $115 \%$; this occurred on May 23 and 24, 2001.

Water-temperature standards that apply to the lower Columbia River are complex and depend on the effects of anthropogenic activities and the locations of salmonid rearing, spawning, and egg incubation areas (Oregon Department of Environmental Quality website at http://www.deq.state.or.us/wq/wqrules.htm, 2001). When the temperature of the Columbia River exceeds $20^{\circ} \mathrm{C}$ from RM 309 to the mouth, no measurable surface water temperature increase resulting from anthropogenic activities is allowed by the Oregon water-quality standard. Water-temperature data for spring and summer 2001 are shown in figure 10. The highest water temperature, $24.7^{\circ} \mathrm{C}$, was recorded at the John Day forebay site on August 12, 2001, at 7:00 p.m. 


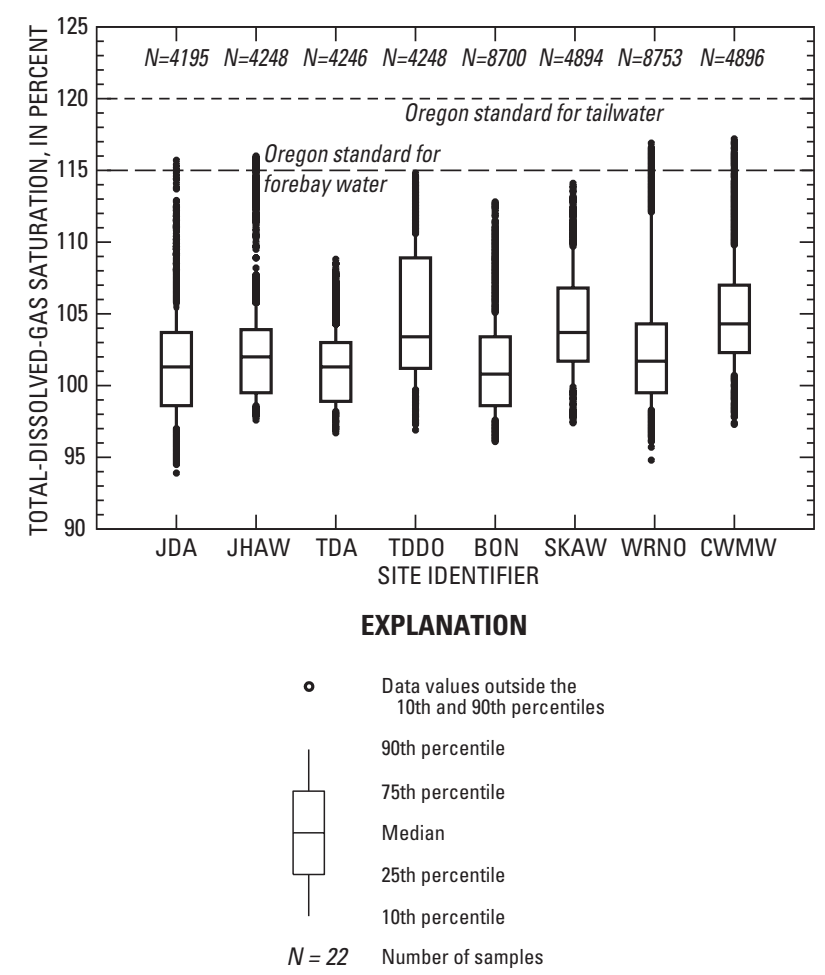

Figure 9. Total-dissolved-gas distributions and Oregon standards at the eight monitoring sites. (Refer to table 1 for site identifier; $\mathrm{N}=$ sample size.)

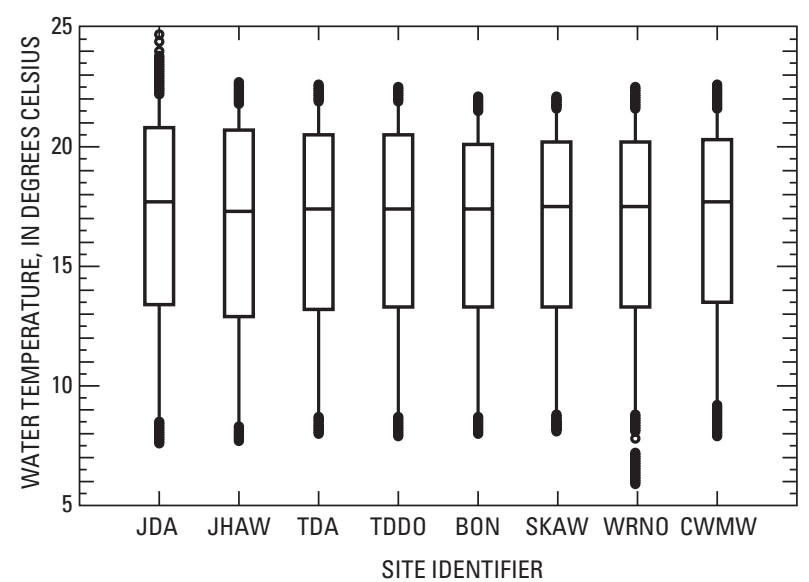

\section{EXPLANATION}

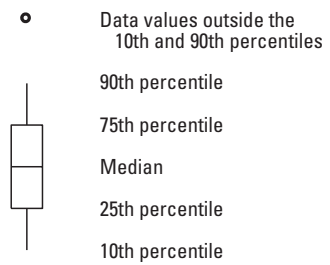

Figure 10. Water-temperature distributions at the eight monitoring sites from April 1 to September 15, 2001. (Refer to table 1 for site identifier. There were 4,032 measurements at each site.)
For each site, the 75th percentile of hourly values was higher than $20^{\circ} \mathrm{C}$. During August, all sites exhibited water temperatures higher than $20^{\circ} \mathrm{C}$.

The distributions of hourly water temperatures for 1 day, August 29, 2001, are shown in figure 11. On that day, water temperatures were higher than $20^{\circ} \mathrm{C}$ at all hours at all sites. Camas was the only site for which the median $\left(22.1^{\circ} \mathrm{C}\right)$ fell outside of the narrow range of 21.6-21.9 ${ }^{\circ} \mathrm{C}$. The elevated temperature at Camas may be due to the physical characteristics of the shallower free-flowing section of the Columbia River near Camas. Water temperatures at John Day forebay were notably higher than at other stations, possibly due to localized heating near the fixed station. The water-temperature variations at Camas and John Day forebay are discussed next in the section on site-specific considerations.

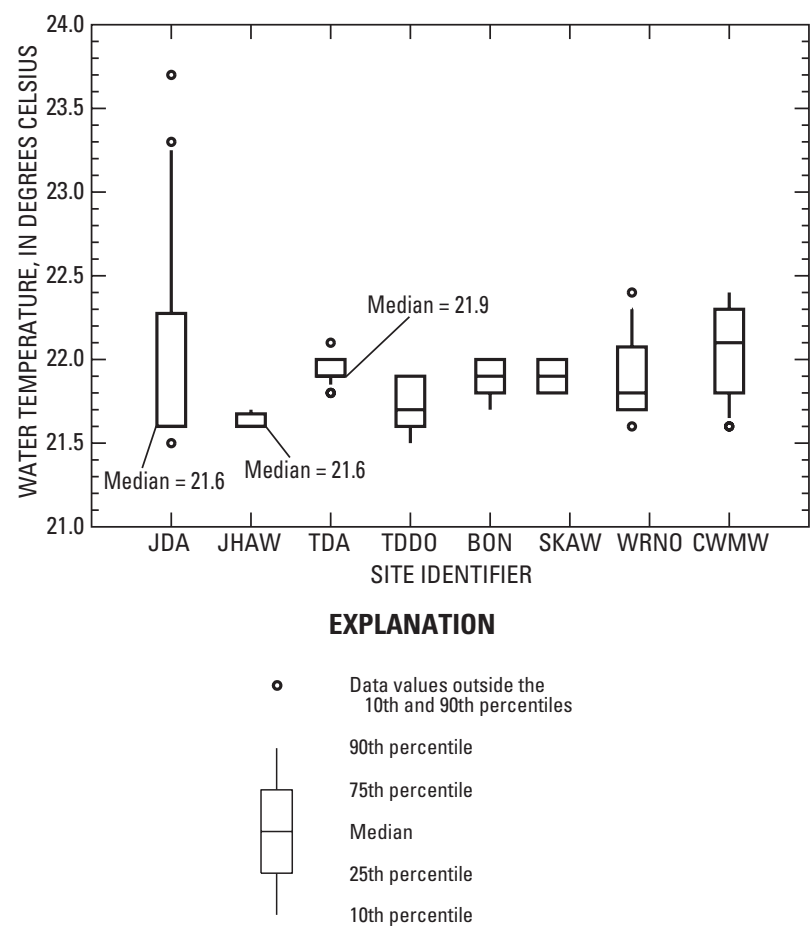

Figure 11. Water-temperature distributions at the eight monitoring sites on August 29, 2001. (Refer to table 1 for site identifier. There were 24 measurements at each site.)

\section{SITE-SPECIFIC CONSIDERATIONS}

Even though the same types of electronic equipment and instruments were used at each site, there were differences among the sites in the stream environment where the equipment was installed along the river banks. Some sites were at river locations that were poorly mixed, had limited probe depth at certain times of the year, or had greater circulation of water around the probe. The important effects of site-specific considerations are summarized next. 


\section{Variability of Total Dissolved Gas and Water Temperature at John Day Forebay}

At the John Day forebay, TDG values rose on several occasions by 3 to $5 \%$ saturation for several hours, concurrent with a 2 to $3^{\circ} \mathrm{C}$ increase in water temperature. Data for several days in August, when there was no spill from John Day Dam, are shown in figure 12. The fact that the temperature below John Day Dam did not vary greatly during this period indicates that the water-temperature excursions at the John Day forebay were anomalous. These excursions of TDG and water temperature were observed on hot, sunny days, and it is believed that a localized parcel of heated water on the river surface caused the increase in water temperature observed at the fixed station.

It was documented by Mike Schneider (USACE, written commun., 2001) that these events happened when winds were nearly calm, a favorable condition for surface heating. TDG and temperature anomalies also were observed in WY 2000 during periods of similar weather conditions (Tanner and Johnston, 2001, p. 19).

\section{Variability of Total Dissolved Gas and Water Temperature at Camas}

During much of the monitoring season at the Camas site, water temperature and TDG were observed to fluctuate in a smooth, diurnal pattern. For example, from May 23 to 25, at about 8:00 a.m., minima were observed for water temperature (about 15 to $15.5^{\circ} \mathrm{C}$ ) and for TDG (about 111 to $112 \%$ saturation) (fig. 13). Maxima were observed at about 5:00 p.m. for water temperature (about 16.5 to $17^{\circ} \mathrm{C}$ ) and for TDG (about 116 to $117 \%$ saturation). There was sufficient flow at the Camas site to preclude any afternoon heating of localized parcels of water as was observed at the John Day forebay site.

One probable cause for the TDG variations is primary productivity in the Columbia River. During the same time period (May 23-26), the USGS measured dissolved oxygen at the Camas site and found variations of the same pattern, with morning minima of $11 \mathrm{mg} / \mathrm{L}$ (milligrams per liter) and afternoon maxima of $12 \mathrm{mg} / \mathrm{L}$ (USGS data files). Water-temperature variations at the Camas site could be due to the shallow, free-flowing river characteristics at Camas that would be very different from the other Columbia River TDG sites, which are affected by the reservoirs.
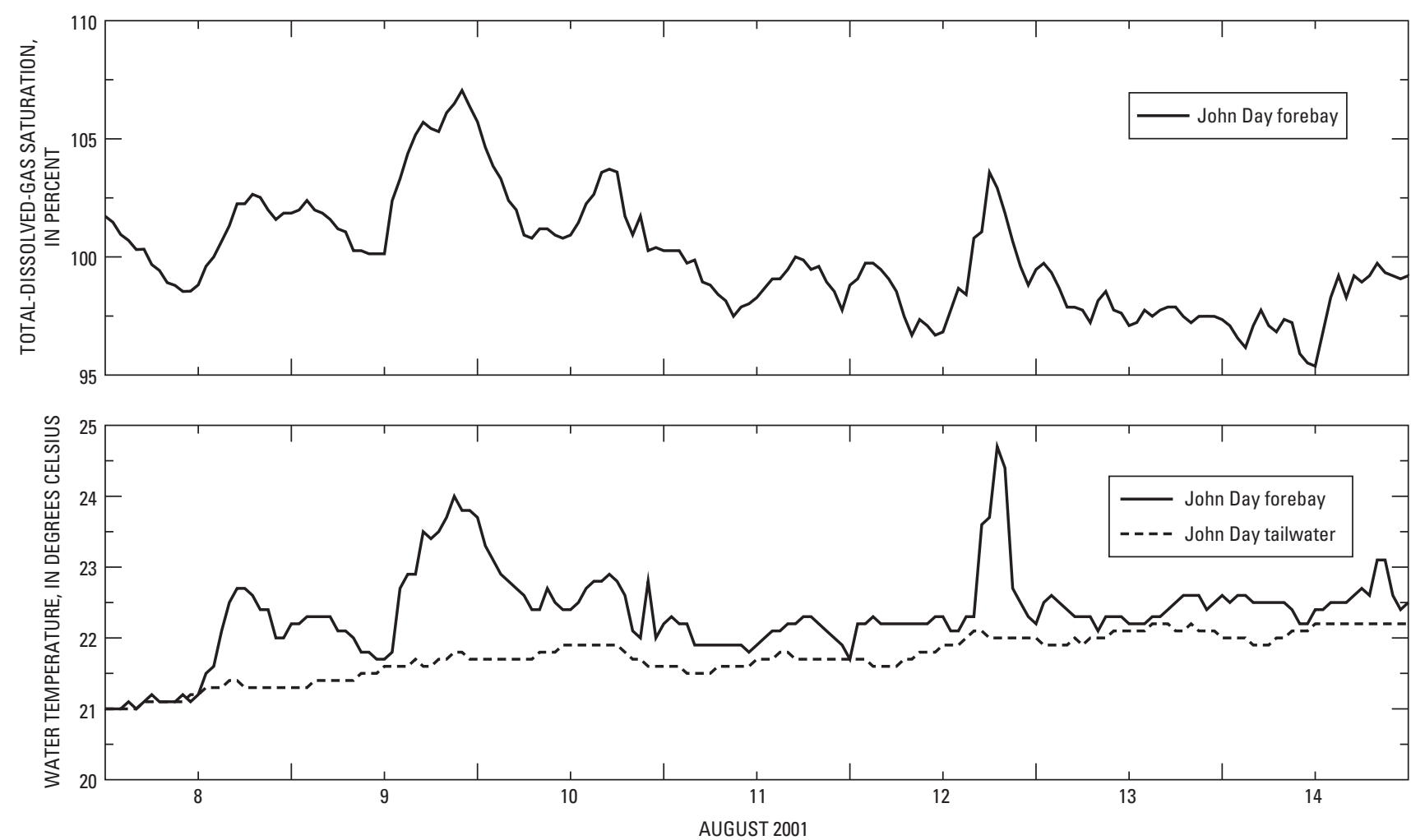

Figure 12. Total dissolved gas at John Day forebay and water temperature at John Day forebay and John Day tailwater. 


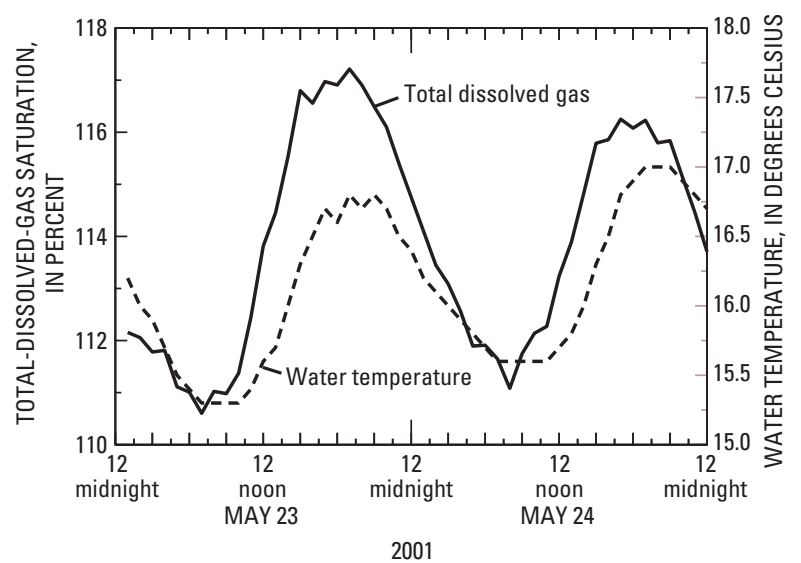

Figure 13. Diurnal variations of total dissolved gas and water temperature at Camas.

Calculations by Joe Carroll, (USACE, written commun., 2001) showed that on May 24, theoretical pressure changes due to the measured temperature and dissolved oxygen variations accounted for a TDG pressure increase of $38 \mathrm{~mm} \mathrm{Hg}$, when an actual increase of $36 \mathrm{~mm} \mathrm{Hg}$ was measured by the TDG sensor at Camas. These independent measures of the components of TDG match TDG measurements well, indicating that the diurnal variations in TDG were probably due to the production of oxygen by aquatic plants and to diurnal temperature variations, and not due to the spill operations of the upstream dams. Depending on the barometric pressure at the time of measurement, the $36-38 \mathrm{~mm}$ of TDG pressure increase would be equivalent to about $5 \%$ saturation, which is significant because this is the same time period (May 23 and 24) that the variance of $115 \%$ saturation was exceeded at Camas.

\section{Lateral Distribution of Total Dissolved Gas at the Skamania-Warrendale Cross Section}

The TDG stations at Skamania, Washington, and Warrendale, Oregon, are almost directly across the Columbia River from one another-their locations differ laterally by only 0.1 river mile (table 1 ). Data from these stations show the river is not well mixed with respect to TDG at this cross section. TDG levels at Skamania and Warrendale for the spring and summer of 2001 are shown on figure 14. If TDG levels for each hourly value had been the same at both sites, the data points would have fallen directly on the line labeled "Slope $=1$." Instead, when the TDG was larger than about $105 \%$ saturation at Skamania, the measured TDG at Warrendale was 3-5\% larger than at Skamania (fig. 14). Water temperatures at these two stations did not differ appreciably from each other during the monitoring season, so it was not a case of heating causing a change in TDG.

The cause of this uneven distribution of TDG in the river cross section was probably related to the configuration of power generation equipment at Bonneville Dam. Powerhouse 2, north of the spill bays at Bonneville, was used to generate power in WY 2001, and flow from the powerhouse forced supersaturated water from the spill bays south to the Oregon side of the Columbia River, where the Warrendale site is located. During spill events, TDG exceeded $105 \%$ saturation at Warrendale (fig. 8), and TDG levels at Warrendale exceeded levels at Skamania by about $3-5 \%$ (fig. 14). Consequently, it is likely that the spill during the use of powerhouse 2 is responsible for the poor mixing in the river at this cross section. This finding illustrates the need for operating both the Skamania and Warrendale monitoring sites to describe TDG levels in the river cross section under varying conditions of spill and power generation.

\section{Compensation Depth at Warrendale}

Compensation depth for TDG measurement is the depth above which degassing is possible. In order to measure TDG accurately, the probe must be deeper than the compensation depth, which is calculated as (TDG pressure, in millimeters of mercury, minus barometric pressure, in millimeters of mercury) divided by 23. This equation was based on a formula derived from Colt (1984, p. 104). If the probe is above the minimum compensation depth, the measured TDG may be less than it would be if measured at a greater depth. In other words, degassing may have occurred.

To ensure that the TDG probe was below the compensation depth when the TDG in the river was $120 \%$ saturation, the following formula could be used to calculate the compensation depth:

$$
C D=[(T D G e / 100) \times B p)-B p] / 23
$$

where

$C D=$ Compensation depth, in feet;

$T D G e=$ Highest expected TDG, in percent saturation;

$B p$ = Barometric pressure in millimeters of mercury. 


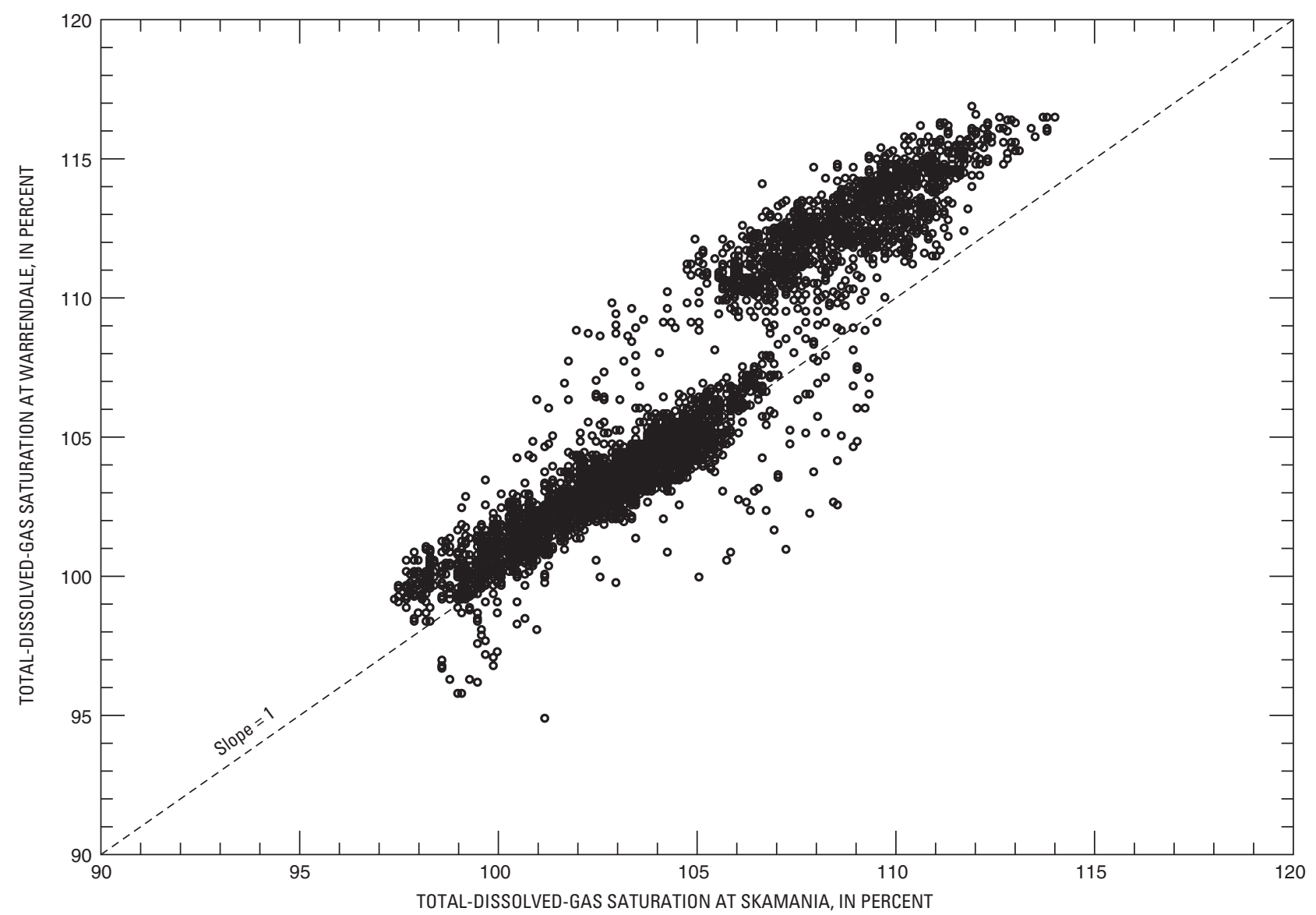

Figure 14. Comparison of total dissolved gas at Warrendale and Skamania. (There were 4,886 measurements at each site.)

For example, if the $B p$ is $760 \mathrm{~mm} \mathrm{Hg}$, and the highest expected TDG level is $120 \%$ saturation, the $C D$ is 6.6 feet. Therefore, the TDG probe must be located at a depth greater than 6.6 feet to avoid potential degassing and the formation of bubbles on the TDG membrane. If the highest expected TDG level in the river is $145 \%$ saturation, then the compensation depth would be 14.9 feet. For the fixed stations on the lower Columbia River, TDG probes were kept at a depth of 15 feet or greater, where possible.

Warrendale was the only site where the TDG probe was above the compensation depth at any time in WY 2001. During the spill from Bonneville Dam from July 24 to August 31, the water depth at the Warrendale fixed station was only a few feet so the probe depth was only about 1.5 to 3 feet. Consequently, the probe was above the compensation depth and degassing may have occurred (fig. 15). Measured TDG at Warrendale then was $110-115 \%$ (fig. 8), and in this range, the TDG is higher at Warrendale than across the river at Skamania (fig. 14). The conclusion to be drawn from these data is that although the Warrendale site was a better place than Skamania to measure elevated TDG at this time, an even higher TDG could possibly have been measured at a deeper location on the Oregon side (or, alternatively, at a location closer to Bonneville Dam).

The problem with attaining sufficient probe depth at Warrendale is related to the physical characteristics of the site. The instruments were housed on a floating wooden dock, and the TDG probe was suspended from the dock. When the river was shallow at the Warrendale site, as it was from mid-July to the end of the water year, the probe was maintained about a foot above the river bottom. In order to measure TDG at a greater depth, the probe would need to be moved to a deeper part of the river at another fixedstation location. 


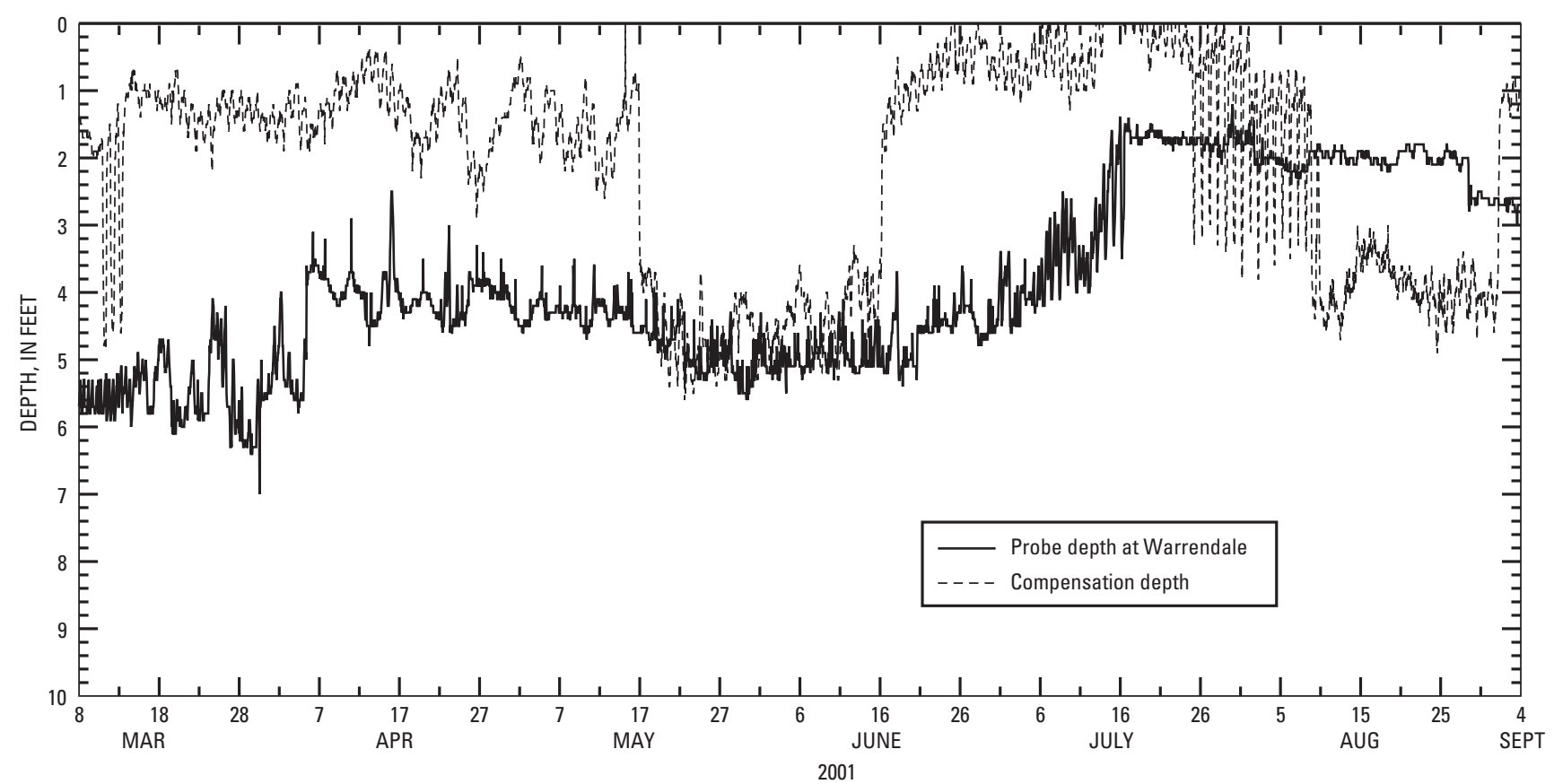

Figure 15. Compensation depth and actual probe depth at Warrendale.

\section{REFERENCES CITED}

Colt, J., 1984, Computation of dissolved gas concentrations in water as functions of temperature, salinity, and pressure: American Fisheries Society Special Publication $14,154 \mathrm{p}$.

Jones, J.C., Tracey, D.C., and Sorensen, F.W., eds., 1991, Operating manual for the U.S. Geological Survey's data-collection system with the Geostationary Operational Environmental Satellite: U.S. Geological Survey Open-File Report 91-99, 237 p.

Tanner, D.Q., Harrison, H.E., and McKenzie, S.W., 1996, Total dissolved gas, barometric pressure, and water temperature data, lower Columbia River, Oregon and Washington, 1996: U.S. Geological Survey Open-File Report 96-662A, 85 p.

Tanner, D.Q., and Johnston, M.W., 2001, Data-collection methods, quality-assurance data, and site considerations for total dissolved gas monitoring, lower Columbia River, Oregon and Washington, 2000: U.S. Geological Survey Water-Resources Investigations Report 01-4005, 19 p.

U.S. Environmental Protection Agency, 1986, Quality criteria for water: Washington, D.C., EPA-440-5-86-001. 
U.S. Department of the Interior

U.S. Geological Survey

\section{Quality-Assurance Data, Comparison to Water-Quality Standards, and Site Considerations for Total Dissolved Gas and Water Temperature, Lower Columbia River, Oregon and Washington, 2001}

Water-Resources Investigations Report 01-4273

Prepared in cooperation with the U.S. ARMY CORPS OF ENGINEERS

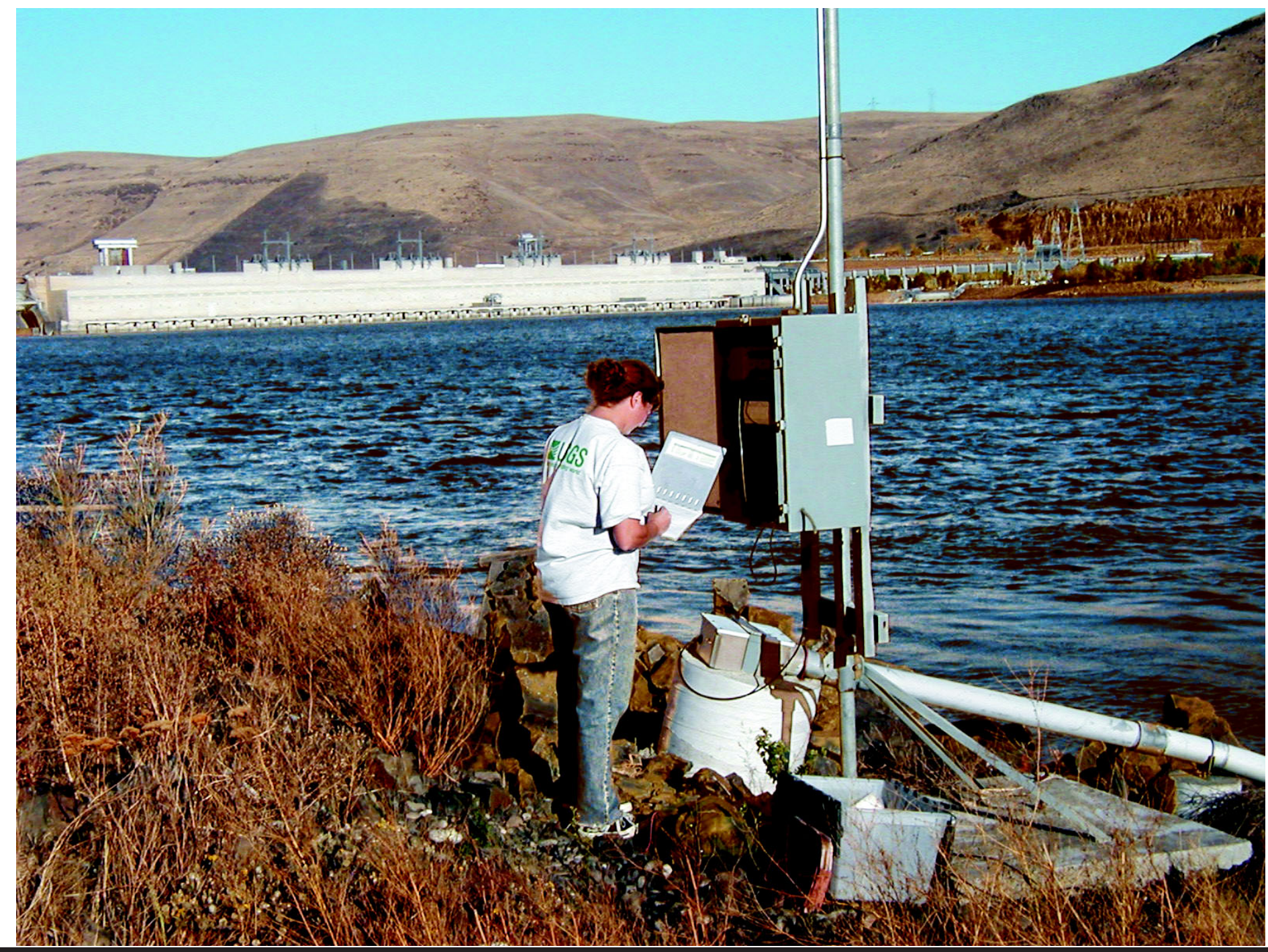




\section{Cover photograph:}

Calibration of monitoring equipment on the Columbia River downstream of John Day Dam, September 2001.

(Photograph by Rebecca Treat, U.S. Geological Survey volunteer) 